\title{
Awareness, Partisanship and the Post-Convention Bounce: A Memory-Based Model of Post- Convention Presidential Candidate Evaluations Part II-Empirical Results
}

\author{
Justin Grimmer \\ Department of Mathematics and Computer Science \\ Wabash College \\ Crawfordsville, Indiana 47933 USA
}

Received: June 6, $2004 \quad$ Accepted: September 24, 2004

\begin{abstract}
This paper continues an analysis, begun in the December 2004 issue, that employed panel data to estimate the effects of awareness and political partisanship on post-convention candidate evaluations. The derivation of a theoretical framework was discussed in Part 1 [1]. Empirical results using data from the US presidential election of 2000 are discussed in the present article. We find that partisans of the opposite party were more resistant to the convention message of Bush than Gore, that awareness played a greater role in determining a predicted post-convention change for Gore, and that Gore's message was received and accepted at a higher rate than Bush's message.
\end{abstract}

\section{EMPIRICAL RESULTS}

\section{a. Description of the Data Set}

The data we will use in estimating Equation 3 of our Part 1 analysis [1] come from two panel studies from the National Annenberg Election Survey surrounding the 2000 nominating conventions. The participants in the study samples were interviewed before and after the Republican and Democratic convention. The Republican sample contains 1,197 respondents, while the Democratic convention sample contains 1,230. However, due to the nature of the analysis, respondents who did not evaluate a candidate in both interviews were eliminated from our analysis of that specific candidate. This reduces to 1,146 and 1,154 respondents for Bush and Gore respectively for the GOP convention. For the Democratic convention, both Bush and Gore samples had 1,186 respondents both before and after the convention.
The dependent variable in the present analysis will be the post-convention feeling thermometer for both candidates and we will use the pre-convention feeling thermometer as an independent variable. Survey Respondents were asked, "On a scale of 0 to 100 how would you rate (Candidate)? Zero means very unfavorable and 100 means very favorable. Fifty means you do not feel favorable or unfavorable. If you don't know enough about the person to rate him just let me know." Thus, the feeling thermometer is a variable that goes from 0 to 100 , and will be treated as an interval variable [2].

The choice independent variables in our analysis consist of two indices: awareness and ideological/partisan strength. The awareness index that we have constructed contains eight items: an interviewer evaluation of respondent knowledge, a test to see if the respondent can correctly place George W. Bush and Al Gore in the correct space along a left-right 
continuum, and six questions regarding candidate biographies. Zaller advocates the use of interviewer grades and tests of knowledge in order to determine the awareness of a respondent [3, pp. 337-339]. The index runs from 0 to 15 possible points. Appendix A of Grimmer [1] contains information regarding the specific questions asked and the distribution of points in the index.

The Political Predisposition and Ideological leaning index is a four-item index that attempts to measure the respondent's ideological position. The index has a maximum value of 4 and a minimum value of -4 . The party that is in convention has the positive score on our recodes. Thus, a strong Democrat in the Republican convention sample has a partisanship score of -4 , while a strong Democrat in the Democratic convention sample has a partisanship score of 4 . Appendix A in [1] contains the specific questions and distribution of points for this index.

Finally, we have included the amount of time spent watching the convention as an independent variable. In the GOP [i.e., the Republican] convention sample, respondents in the second wave were asked how much time they had spent watching the convention. In the Democratic convention Sample, respondents in the first wave were asked how much time they had spent watching the GOP convention, then in the second wave were asked about amount of time spent watching the Democratic convention. The variables will be included as dichotomous variables for each level of engagement with the convention.

In previous work we have shown that a continuous assumption for a noncontinuous variable hides variation regarding the effects of the independent variable on the dependent variable. Further, the coding methods of the survey make a continuous interval difficult [1].

Descriptions of the variables that are employed in this analysis are displayed in Table 1. Tables 2 (a) and (b) display summary statistics for the Republican and Democratic Convention samples.

b. Estimation of the Model and Analysis

In order to establish patterns of candidate assessment around conventions,
Graph 1 below shows the percentage of respondents that reported an intended vote for Bush or Gore in a repeated crosssectional survey conducted during the 2000 campaign [5]. During the summer of 2000 the percentage of respondents that reported an intended vote for candidates remained relatively constant, with approximately $5 \%$ more people reporting an intended vote for Bush rather than Gore. The first large jump in intended vote for a candidate occurs after the Republican convention, with $54 \%$ of respondents stating they intended to vote for Bush, compared to $40 \%$ that reported an intended vote for Al Gore. However, after the Democratic convention there is a large increase in intended vote for Gore, increasing to $50 \%$ of respondents and the total stating an intended vote for Bush decreasing 9 percentage points from the post-convention high to $45 \%$. Both candidates received an increase in public support after their nominating conventions; however, was this same pattern reflected in the panel data? What role did awareness and partisanship play in differing evaluations of opinions?

In order to determine the effect of the nominating conventions on individual respondents' evaluations of the candidates, four models were estimated with the postconvention feeling thermometer of both Gore and Bush as dependent variables. Models 1 and 2 predict post-convention feeling thermometers after the Republican convention and Models 3 and 4 model postconvention feeling thermometers after the Democratic convention.

First, it is important to note that we have a high number of statistically insignificant variables. However, awareness appears three times in our model, and Ideology and Partisanship appears in two variables. The inclusion of each term several times results in severe multi-collinearity. Zaller, whose models suffer from similar statistical imprecision, argues that modern statistical theory states that standard errors and confidence intervals are less important than consistent performance over different data sets that fit within a strong theoretical framework [3, pp. 290-291]. The estimated parameters in our model (Table 3 ) fit within the predicted sign of the reception-acceptance model, with only 


\begin{tabular}{|c|c|c|}
\hline Number & Name & Description \\
\hline \multicolumn{3}{|c|}{ DEPENDENT VARIABLE } \\
\hline 1 & Post-Convention Feeling Thermometer & $\begin{array}{l}\text { Continuous Variable, } 0 \text { if Unfavorable, } \\
100 \text { if very favorable, asked in Second } \\
\text { Wave }\end{array}$ \\
\hline \multicolumn{3}{|c|}{ INDEPENDENT VARIABLES } \\
\hline 2 & Pre-Convention Feeling Thermometer & $\begin{array}{l}\text { Continuous Variable, } 0 \text { if Unfavorable, } 100 \text { if } \\
\text { very favorable, asked in first wave }\end{array}$ \\
\hline 3 & Awareness & $\begin{array}{l}\text { Continuous Variable (Index) Measuring } \\
\text { Respondent Awareness }\end{array}$ \\
\hline 4 & Awareness $^{2}$ & $\begin{array}{l}\text { Continuous Variable, Measured Awareness } \\
\text { Squared }\end{array}$ \\
\hline 5 & Awareness*Partisanship/ldeology & $\begin{array}{l}\text { Interaction Term, Awareness Index Multiplied } \\
\text { by Partisanship Index }\end{array}$ \\
\hline 6 & Partisanship/ldeology & $\begin{array}{l}\text { Continuous Variable (Index) Positive if } \\
\text { Partisanship is the Same as the Party in } \\
\text { Convention, Negative Otherwise }\end{array}$ \\
\hline 7 & Did Not Watch GOP Convention & $\begin{array}{l}\text { Dummy Variable, } 1 \text { if respondent did not } \\
\text { watch GOP Convention, } 0 \text { otherwise }\end{array}$ \\
\hline 8 & $\begin{array}{l}\text { Watched GOP Convention a Few } \\
\text { Minutes }^{\dagger}\end{array}$ & $\begin{array}{l}\text { Dummy Variable, } 1 \text { if respondent watched } \\
\text { GOP convention a few minutes, } 0 \text { otherwise }\end{array}$ \\
\hline 10 & $\begin{array}{l}\text { Watched GOP Convention a Half- } \\
\text { Hour }\end{array}$ & $\begin{array}{l}\text { Dummy Variable, } 1 \text { if respondent watched } \\
\text { GOP convention a half hour, } 0 \text { otherwise }\end{array}$ \\
\hline 11 & Watched GOP Convention One-Hour & $\begin{array}{l}\text { Dummy Variable, } 1 \text { if respondent watched } \\
\text { GOP convention for One-Hour, } 0 \text { otherwise }\end{array}$ \\
\hline 12 & Watched GOP Convention 2+ & $\begin{array}{l}\text { Dummy Variable, } 1 \text { if respondent watched } \\
\text { GOP convention for Two or more Hours, } 0 \\
\text { otherwise }\end{array}$ \\
\hline 13 & Did Not Watch Dem Convention & $\begin{array}{l}\text { Dummy Variable, } 1 \text { if respondent did not } \\
\text { watch Dem. Convention, } 0 \text { otherwise }\end{array}$ \\
\hline 14 & $\begin{array}{l}\text { Watched Dem Convention a Few } \\
\text { Minutes }^{\dagger}\end{array}$ & $\begin{array}{l}\text { Dummy Variable, } 1 \text { if respondent watched a } \\
\text { Few Minutes, } 0 \text { otherwise }\end{array}$ \\
\hline 15 & $\begin{array}{l}\text { Watched Dem Convention a Half- } \\
\text { Hour }\end{array}$ & $\begin{array}{l}\text { Dummy Variable, } 1 \text { if respondent watched } \\
\text { Dem. Convention a Half-Hour, } 0 \text { otherwise }\end{array}$ \\
\hline 16 & Watched Dem Convention One-Hour & $\begin{array}{l}\text { Dummy Variable, } 1 \text { if respondent watched } \\
\text { Dem. Convention an Hour, } 0 \text { otherwise }\end{array}$ \\
\hline 17 & Watched Dem Convention 2+ Hours & $\begin{array}{l}\text { Dummy Variable, } 1 \text { if respondent watched } \\
\text { Dem. Convention for two or more hours, } 0 \\
\text { otherwise }\end{array}$ \\
\hline
\end{tabular}

Table 1. Description of the variables used in this analysis.

† Watched GOP/DEM Convention for a few minutes and for a half hour will be excluded in this analysis to avoid multi-collinearity. 


\begin{tabular}{|c|c|c|c|c|}
\hline Variable & Mean & $\begin{array}{c}\text { Standard } \\
\text { Deviation }(\sigma)\end{array}$ & Maximum & Minimum \\
\hline $\begin{array}{l}\text { Bush Post-convention Feeling } \\
\text { Thermometer }\end{array}$ & 60.36 & 29.69 & 1 & 0 \\
\hline $\begin{array}{l}\text { Gore Post-convention Feeling } \\
\text { Thermometer }\end{array}$ & 50.09 & 29.75 & 1 & 0 \\
\hline $\begin{array}{l}\text { Bush Pre-Convention Feeling } \\
\text { Thermometer }\end{array}$ & 57.02 & 30.64 & 1 & 0 \\
\hline $\begin{array}{l}\text { Gore Pre-Convention Feeling } \\
\text { Thermometer }\end{array}$ & 48.57 & 30.64 & 1 & 0 \\
\hline Awareness & 9.2 & 3.24 & 15 & 0 \\
\hline Awareness $^{2}$ & 95.44 & 56.82 & 225 & 0 \\
\hline $\begin{array}{l}\text { Awareness* } \\
\text { Partisanship/ldeology }\end{array}$ & 1.97 & 19.91 & 60 & -60 \\
\hline $\begin{array}{l}\text { Partisanship and Ideological } \\
\text { Leaning }\end{array}$ & 0.155 & 1.89 & 4 & -4 \\
\hline $\begin{array}{l}\text { Did Not Watch GOP } \\
\text { Convention }\end{array}$ & 0.41 & 0.49 & 1 & 0 \\
\hline $\begin{array}{l}\text { Watched GOP Convention for } \\
\text { a few minutes }\end{array}$ & 0.093 & 0.29 & 1 & 0 \\
\hline $\begin{array}{l}\text { Watched GOP Convention for } \\
\text { a Half-Hour }\end{array}$ & 0.129 & 0.335 & 1 & 0 \\
\hline $\begin{array}{l}\text { Watched GOP Convention for } \\
\text { an Hour }\end{array}$ & 0.11 & 0.32 & 1 & 0 \\
\hline $\begin{array}{l}\text { Watched GOP Convention for } \\
\text { Two or More Hours }\end{array}$ & 0.25 & 0.44 & 1 & 0 \\
\hline
\end{tabular}

Table 2 (a). A summary of the statistics for the Republican Convention sample.

two signs deviating from the predicted direction, Watched Democratic Convention an Hour in model 4 and Did Not Watch GOP Convention in Model 2. Therefore, the crucial variables that we derived from the hypotheses, while not statistically significant, are all in the predicted direction. Given that the framework of our model fits within the prediction of the reception-acceptance model, we will proceed to analyze the data in spite of the wide confidence intervals leading to null hypotheses that cannot be rejected.

In order to better interpret the results of my analysis, we will simulate, or replicate over varying levels of awareness, the results of the four estimated models. Our three respondents will be a strong Democrat, an Independent, and a strong Republican. The strong Democrat has a
Partisan and Ideology score of 3 for the Democratic convention and -3 for the Republican convention. The Independent has a score of 0 for both conventions, while the strong Republican has a score of -3 in the Democratic convention and 3 in the Republican convention. Table 4 displays the characteristics of the respondents.

All respondents are assumed to have watched the convention for an hour. A previous feeling thermometer is not given, because we are determining predicted change, that is,

$$
Y_{t+1}-\beta \cdot Y_{t}=\beta_{0}+\sum_{p=1}^{n} \beta_{p} \cdot X_{p}+\varepsilon_{i}
$$

which allows an estimation of change in feeling thermometer, without an assumption that there is a one-to-one relationship 


\begin{tabular}{|c|c|c|c|c|}
\hline Variable & Mean & $\begin{array}{c}\text { Standard } \\
\text { Deviation }(\sigma)\end{array}$ & Maximum & Minimum \\
\hline $\begin{array}{l}\text { Bush Post-convention Feeling } \\
\text { Thermometer }\end{array}$ & 58.95 & 29.42 & 100 & 0 \\
\hline $\begin{array}{l}\text { Gore Post-convention Feeling } \\
\text { Thermometer }\end{array}$ & 58.475 & 30.87 & 100 & 0 \\
\hline $\begin{array}{l}\text { Bush Pre-Convention Feeling } \\
\text { Thermometer }\end{array}$ & 60.55 & 31.17 & 100 & 0 \\
\hline $\begin{array}{l}\text { Gore Pre-Convention Feeling } \\
\text { Thermometer }\end{array}$ & 52.07 & 32.57 & 100 & 0 \\
\hline Awareness & 9.60 & 3.248 & 15 & 0 \\
\hline Awareness $^{2}$ & 102.76 & 58.67 & 225 & 0 \\
\hline $\begin{array}{l}\text { Awareness* Partisanship/ } \\
\text { Ideology }\end{array}$ & -2.29 & 21.21 & 60 & -60 \\
\hline $\begin{array}{l}\text { Partisanship and Ideological } \\
\text { Leaning }\end{array}$ & -0.160 & 1.95 & 4 & -4 \\
\hline $\begin{array}{l}\text { Did Not Watch GOP } \\
\text { Convention }\end{array}$ & 0.404 & 0.491 & 1 & 0 \\
\hline $\begin{array}{l}\text { Watched GOP Convention for } \\
\text { a few minutes }\end{array}$ & 0.086 & 0.281 & 1 & 0 \\
\hline $\begin{array}{l}\text { Watched GOP Convention for } \\
\text { a Half-Hour }\end{array}$ & 0.106 & 0.307 & 1 & 0 \\
\hline $\begin{array}{l}\text { Watched GOP Convention for } \\
\text { an Hour minutes }\end{array}$ & 0.133 & 0.34 & 1 & 0 \\
\hline $\begin{array}{l}\text { Watched GOP Convention for } \\
\text { Two or More Hours }\end{array}$ & 0.271 & 0.44 & 1 & 0 \\
\hline $\begin{array}{l}\text { Did Not Watch Dem. } \\
\text { Convention }\end{array}$ & 0.364 & 0.481 & 1 & 0 \\
\hline $\begin{array}{l}\text { Watched Dem. Convention } \\
\text { for a few minutes }\end{array}$ & 0.1089 & 0.312 & 1 & 0 \\
\hline $\begin{array}{l}\text { Watched Dem Convention for } \\
\text { a Half-Hour }\end{array}$ & 0.128 & 0.333 & 1 & 0 \\
\hline $\begin{array}{l}\text { Watched Dem Convention for } \\
\text { an Hour }\end{array}$ & 0.115 & 0.32 & 1 & 0 \\
\hline $\begin{array}{l}\text { Watched Dem Convention for } \\
\text { Two or More Hours }\end{array}$ & 0.284 & 0.451 & 1 & 0 \\
\hline
\end{tabular}

Table 2 (b). A summary of the statistics for the Democratic Convention sample.

thermometer and the post-convention feeling thermometer ([3] p. 107).

We will first simulate the results of Model 1 and Model 3. Graph 2 displays the effect of awareness on post convention feeling thermometer for Bush, controlling for the previous feeling thermometer score, which we are interpreting as previous considerations (Model 1). First, as the theoretical model predicts, there is a partisan resistance associated with evaluation of Bush. Democrats, who would view the message of the Republican convention as contradictory to their 


\begin{tabular}{|c|c|c|c|c|}
\hline & $\begin{array}{c}\text { Bush Post GOP } \\
\begin{array}{c}\text { Convention } \\
\text { (Model 1) }\end{array} \\
\end{array}$ & $\begin{array}{c}\text { Gore Post GOP } \\
\text { Convention } \\
\text { (Model 2) }\end{array}$ & $\begin{array}{c}\text { Gore Post Dem } \\
\text { Convention } \\
\text { (Model 3) }\end{array}$ & $\begin{array}{c}\text { Bush Post Dem } \\
\text { Convention } \\
\text { (Model 4) }\end{array}$ \\
\hline Intercept & $\begin{array}{c}20.66^{* * *} \\
(5.43) \\
\end{array}$ & $\begin{array}{c}19.45^{\star * *} \\
(4.87) \\
\end{array}$ & $\begin{array}{l}9.26^{* *} \\
(2.03)\end{array}$ & $\begin{array}{c}17.26^{* * *} \\
(3.95) \\
\end{array}$ \\
\hline Pre-Convention Ranking & $\begin{array}{c}0.64^{* * *} \\
(31.26) \\
(+)\end{array}$ & $\begin{array}{l}0.65^{* * *} \\
(29.93) \\
(+)\end{array}$ & $\begin{array}{c}0.601^{* * *} \\
(28.74) \\
(+)\end{array}$ & $\begin{array}{c}0.58^{* * *} \\
(26.8) \\
(+)\end{array}$ \\
\hline Awareness & $\begin{array}{c}0.75 \\
(0.92) \\
(+) \\
\end{array}$ & $\begin{array}{c}0.1379 \\
(0.16) \\
(+)\end{array}$ & $\begin{array}{c}4.34^{* * *} \\
(4.75) \\
(+) \\
\end{array}$ & $\begin{array}{c}0.963 \\
(1.12) \\
(+) \\
\end{array}$ \\
\hline Awareness $^{2}$ & $\begin{array}{c}-0.056 \\
(-1.23) \\
(-)\end{array}$ & $\begin{array}{c}-0.014 \\
(-0.29) \\
(-)\end{array}$ & $\begin{array}{c}-0.245^{\star * *} \\
(-5.01) \\
(-)\end{array}$ & $\begin{array}{c}-0.05 \\
(-1.08) \\
(-)\end{array}$ \\
\hline $\begin{array}{l}\text { Ideology and } \\
\text { Partisanship }\end{array}$ & $\begin{array}{c}2.875^{* * *} \\
(2.91) \\
(+) \\
\end{array}$ & $\begin{array}{c}-2.25^{* *} \\
(-2.18) \\
(-) \\
\end{array}$ & $\begin{array}{c}2.122^{* *} \\
(1.94) \\
(+)\end{array}$ & $\begin{array}{c}-2.259^{* *} \\
(-2.11) \\
(-) \\
\end{array}$ \\
\hline $\begin{array}{l}\text { Awareness } x \text { Ideology } \\
\text { and Partisanship }\end{array}$ & $\begin{array}{c}0.0347 \\
(0.37) \\
(+)\end{array}$ & $\begin{array}{c}-0.064 \\
(-0.65) \\
(-)\end{array}$ & $\begin{array}{c}0.056 \\
(0.56) \\
(+)\end{array}$ & $\begin{array}{c}-0.085 \\
(-0.87) \\
(-)\end{array}$ \\
\hline $\begin{array}{c}\text { Did Not Watch GOP } \\
\text { Convention }\end{array}$ & $\begin{array}{c}-1.248 \\
(-0.91) \\
(-) \\
\end{array}$ & $\begin{array}{c}-0.622 \\
(-0.43) \\
(+)\end{array}$ & $\begin{array}{c}2.989^{*} \\
(1.86) \\
(+)\end{array}$ & $\begin{array}{c}-1.531 \\
(-0.97) \\
(-) \\
\end{array}$ \\
\hline $\begin{array}{c}\text { Watched GOP } \\
\text { Convention for an Hour }\end{array}$ & $\begin{array}{c}3.02^{*} \\
(1.6) \\
(+)\end{array}$ & $\begin{array}{c}-0.359 \\
(-0.18) \\
(-)\end{array}$ & $\begin{array}{c}-1.296 \\
(-0.66) \\
(-)\end{array}$ & $\begin{array}{c}0.987 \\
(0.51) \\
(+)\end{array}$ \\
\hline $\begin{array}{c}\text { Watched GOP } \\
\text { Convention for Two } \\
\text { Hours }\end{array}$ & $\begin{array}{l}3.73^{* * *} \\
(2.34) \\
(+)\end{array}$ & $\begin{array}{c}-0.86 \\
(-0.52) \\
(-)\end{array}$ & $\begin{array}{c}-0.908 \\
(-0.49) \\
(-)\end{array}$ & $\begin{array}{c}4.08^{\star *} \\
(2.24) \\
(+)\end{array}$ \\
\hline $\begin{array}{c}\text { Did Not Watch Dem } \\
\text { Convention }\end{array}$ & $\begin{array}{l}- \\
-\end{array}$ & $\begin{array}{l}- \\
-\end{array}$ & $\begin{array}{c}-4.03^{* * *} \\
(-2.62) \\
(-) \\
\end{array}$ & $\begin{array}{c}4.86^{* * *} \\
(3.21) \\
(+) \\
\end{array}$ \\
\hline $\begin{array}{l}\text { Watched Dem } \\
\text { Convention for an Hour }\end{array}$ & - & $\begin{array}{l}- \\
-\end{array}$ & $\begin{array}{c}1.868 \\
(0.95) \\
(+)\end{array}$ & $\begin{array}{c}0.22 \\
(0.12) \\
(-)\end{array}$ \\
\hline $\begin{array}{c}\text { Watched Dem } \\
\text { Convention for Two } \\
\text { Hours }\end{array}$ & $\begin{array}{l}- \\
-\end{array}$ & $\begin{array}{l}- \\
-\end{array}$ & $\begin{array}{c}7.00^{* * *} \\
(4.01) \\
(+)\end{array}$ & $\begin{array}{c}-2.01 \\
(-1.17) \\
(-) \\
\end{array}$ \\
\hline $\mathbf{R}^{2}$ & 0.658 & 0.621 & 0.646 & 0.622 \\
\hline
\end{tabular}

Table 3. Estimation of Equation (3) in Grimmer [1] for the Post-convention Feeling Thermometer. Two-tail T-values are given in parentheses. The sign of the parameter, as predicted by the theory, is below the t-tests; * denotes $0.05<p \leq 0.1$, ${ }^{* *}$ denotes $0.01<p \leq 0.05$, and ${ }^{* * *}$ denotes $p \leq 0.01$.

considerations, tend to have a less favorable view of Bush after the Republican convention than Independents or $\mathrm{Re}$ publicans.

In addition, there is resistance associated with a higher level of awareness.
We see that highly aware Republicans, Independents, and Democrats tend to have a lower evaluation of Bush, controlling for pre-convention feeling thermometer. However, we see that there is not a strong decrease in evaluations of Bush, and that 


\section{Percentage of Registered Voters Intending to Vote for Gore and Bush}
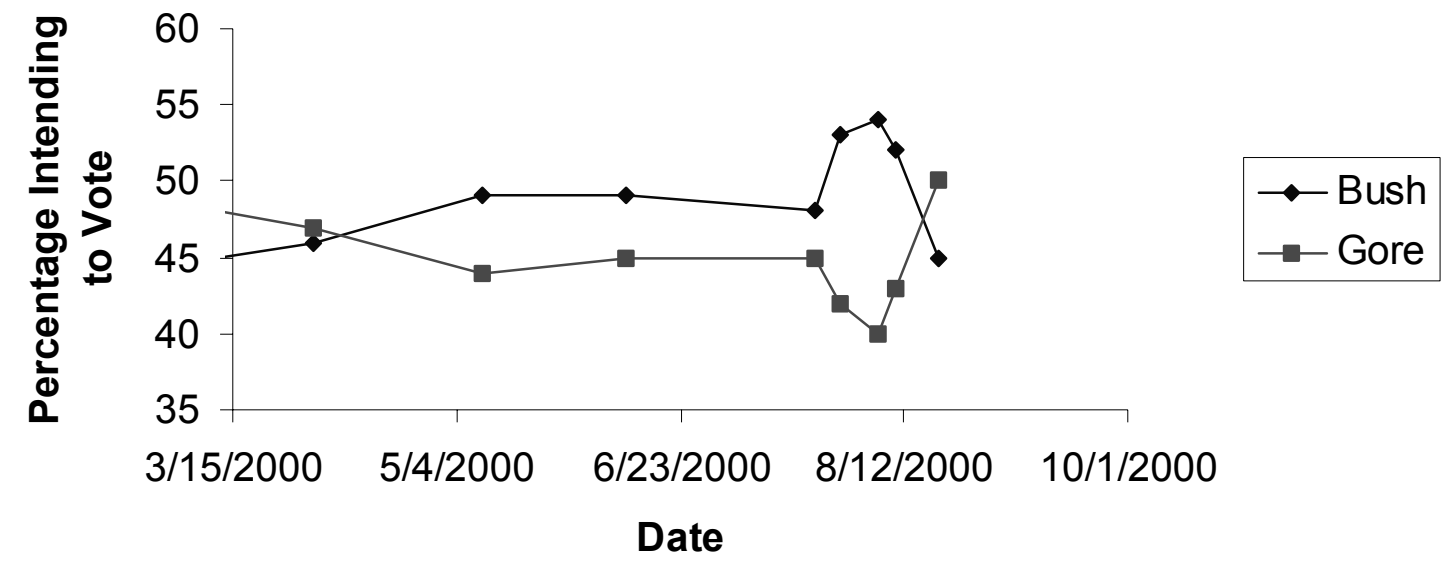

Graph 1. Percentage of registered voters intending to vote for Bush or Gore.

\begin{tabular}{|c|c|c|c|c|}
\hline & \multicolumn{2}{|c|}{ Partisan and Ideology } & \multirow{2}{*}{$\begin{array}{l}\text { Amount of time } \\
\text { Watching Dem } \\
\text { Convention }\end{array}$} & \multirow{2}{*}{$\begin{array}{c}\text { Amount of time } \\
\text { Watching GOP } \\
\text { Convention }\end{array}$} \\
\hline & $\begin{array}{c}\text { Dem } \\
\text { Convention }\end{array}$ & $\begin{array}{c}\text { GOP } \\
\text { Convention }\end{array}$ & & \\
\hline Strong Democrat & 3 & -3 & 1 & 1 \\
\hline Independent & 0 & 0 & 1 & 1 \\
\hline Strong Republican & -3 & 3 & 1 & 1 \\
\hline
\end{tabular}

Table 4. Summary of respondent characteristics.

the non-monotonic bend is not large. The difference between the maximum and minimum value of strong Democrats is 3.79 points and for Republicans only 2.25. Therefore, the effects of Axiom 1 and Axiom 2 are present for the message from the Bush convention. However, the impact of greater awareness on evaluation is not nearly as large as the effects from political predispositions.

How did the effect of Political and Ideological Position and Awareness on evaluations of Al Gore after the Democratic convention differ from the effects for Bush after the Republican convention? Graph 3 below shows the effect of awareness on post convention feeling thermometer for $\mathrm{Al}$ Gore, controlling for previous considerations (Model 3). Here, there is a partisan resistance to the message of Gore, but it is not to the same degree as the resistance to the Bush message after the Republican convention. The difference between the evaluation of Bush between strong Democrats and Republicans at an awareness level of 1 is 17.46 points, while for Gore it is only 13.068. Similarly, the difference between strong partisans at an awareness level of 14 for Bush after the Republican convention is 20.16 points and for Gore only 17.44 points. Therefore, we see that Democrats after the Republican convention were more resistant to the message of Bush than Republicans were to Gore's message after the Democratic convention.

How did the effect of awareness on post-convention feeling thermometers differ between the Republican and Democratic convention? In order to compare the impact of awareness on Post-convention feeling thermometer, we have plotted the first order 


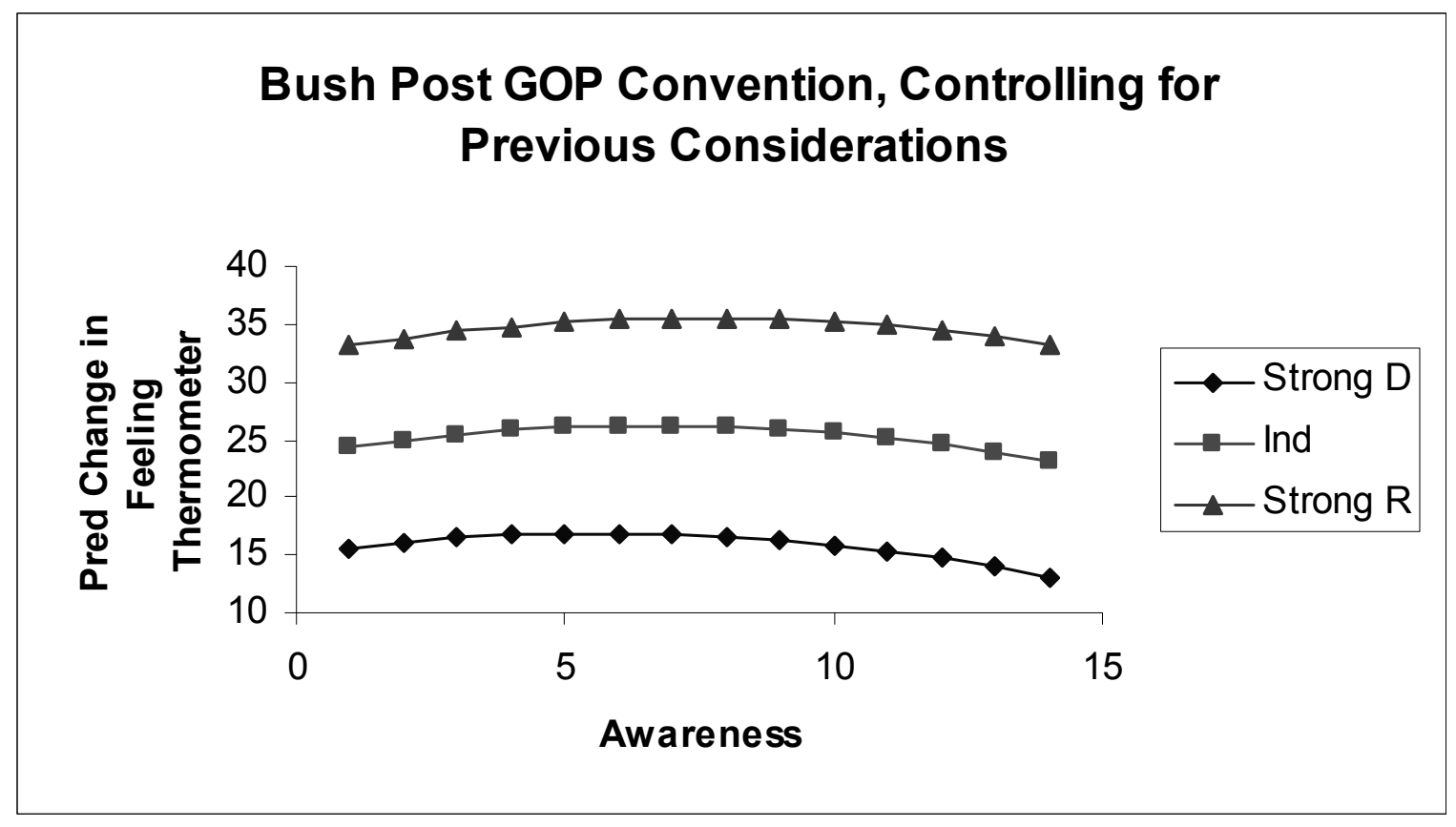

Graph 2. The predicted change in the Feeling thermometer for Bush after the Republican Convention.

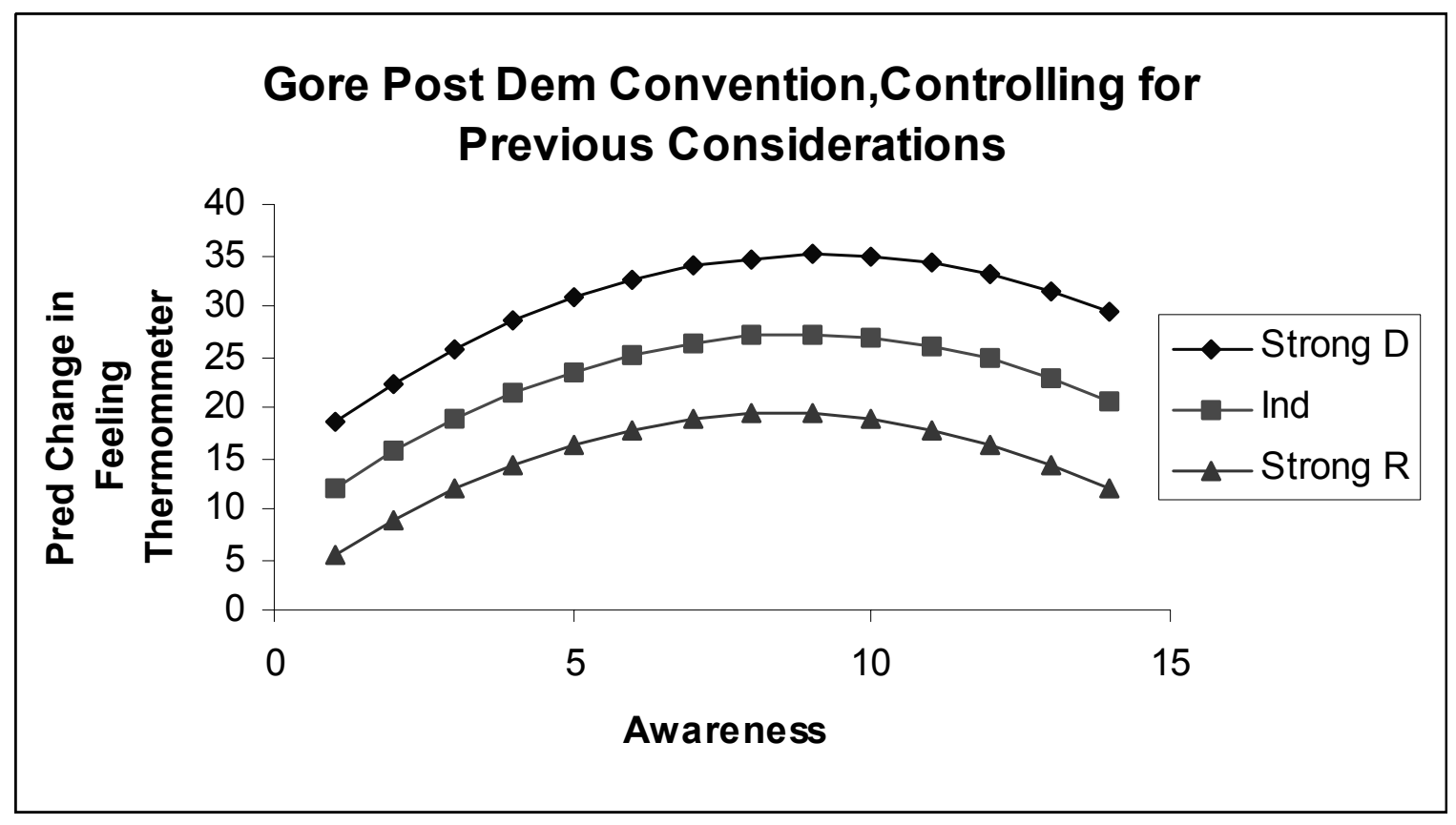

Graph 3. The predicted change in the Feeling thermometer for Gore after the Democratic Convention.

derivative of predicted feeling thermometer change, with respect to awareness in Graph 4. The first order derivative is a method for determining the rate of change with regards to a certain variable in the analysis. For example, the first derivative of the Post 


\section{First order derivative, with respect to awareness}

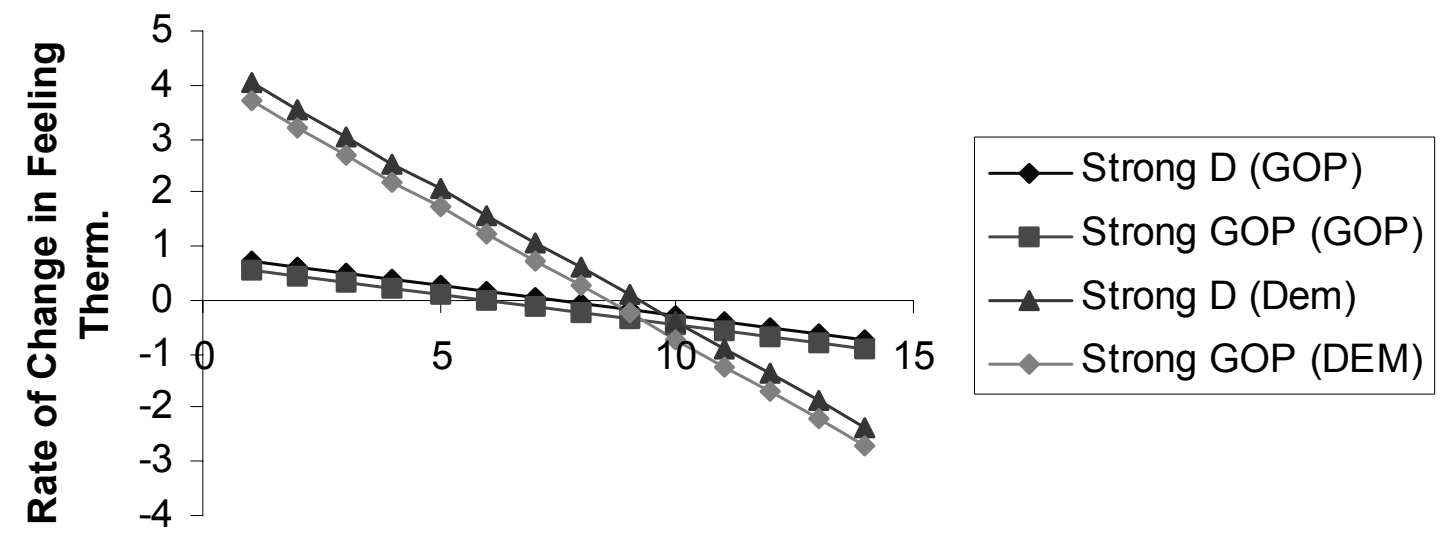

Awareness

Graph 4. The first derivative of the Feeling Thermometer with respect to Awareness.

Convention Feeling Thermometer (see equation (3) in Grimmer [1]) is

$$
\begin{array}{r}
\frac{\partial(P C F T)}{\partial(\text { Awareness })}=\beta_{1}+2 \beta_{2} \\
+\beta_{3}(\text { Partisanhip + Id Dist })
\end{array}
$$

From Graph 4, we see that strong partisans after the Democratic convention had a much quicker, and therefore steeper, rate of change with regards to awareness.

What does this imply? A steeper rate of change after the Democratic convention suggests that increasingly low levels of awareness, holding included variables constant, would result in a higher post-convention evaluation of Gore, due to the intersection of the strong pro-Gore message from the convention. However, higher levels of awareness are associated with a fairly rapid decrease in evaluations of Gore, holding pre-convention considerations constant. A similar phenomenon occurs among evaluations of Bush after the Republican convention; however, the slope is less steep. Awareness played a greater role in determining post-convention response for respondents after the Democratic convention than after the Republican convention.
After the Republican convention respondents showed a greater degree of partisan resistance when evaluating Bush and that awareness played a greater role among respondents after the Democratic convention when evaluating Gore. However, controlling for pre-convention considerations, who received the better evaluations? In order to answer this question, we subtracted the post-convention ranking of Gore from the post-convention ranking of Bush. To see how the messages performed among equivalent groups, we subtracted Strong Democrats after the Democratic convention evaluating Gore from the response of strong Republicans evaluating Bush after the Republican convention. Similarly, we subtracted independents in both samples and strong Republicans after the Democratic convention from strong Democrats after the Republican convention. Thus, in Graph 5 below we can see how the candidates fared with same party, independents, and out of party evaluators, by awareness level.

Graph 5 shows that Bush performs better with individuals with a lower awareness level, holding previous feeling thermometer scores constant. However, among those of higher awareness levels, Gore has a higher evaluation. This fact 


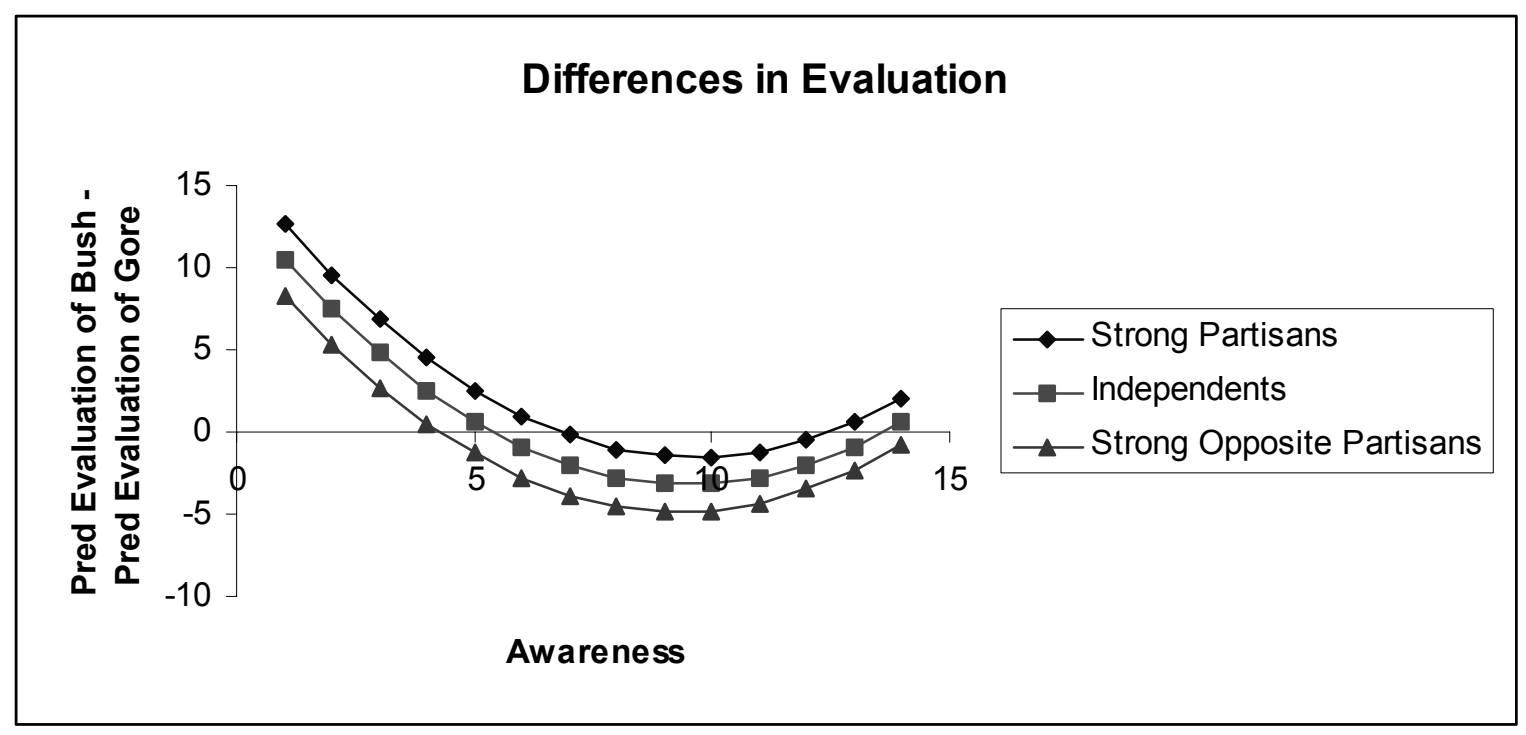

Graph 5. The predicted evaluation of each candidate as a function of Awareness.

becomes more striking when we consider that $90 \%$ of the sample has an awareness level greater than or equal to 5 . Therefore, Gore was able to receive a relatively higher evaluation than Bush among the majority of the respondents. This may explain why Gore's post-convention bounce was larger than Bush's at the aggregate level: his message was more attractive to moderate to highly aware respondents, across each partisan group.

What happens to evaluations of candidates when the opposing candidate is in convention? Model 2 is an estimation of equation 3 [4] among respondents evaluating Gore after the Republican convention, and Model 4 is estimated on respondents evaluating Bush after the Democratic convention. From the theory, we expect that as awareness increases, there should be a polarization among strong partisans. Strong Partisans who are highly aware will evaluate their own candidate highly after a convention, given their ability to situate the message of the opposing convention within the context of their considerations. Further, Strong Partisans whose candidate is in convention should evaluate the opposing candidate quite low and we may see that as highly aware respondents acquire more information, they will be likely to internalize negative considerations regarding the opposing candidates.
Graphs 6 and 7 represent simulations with the same respondent groups in Table 4. First, there is a high degree of polarization between Republicans and Democrats in both graphs, as predicted by the theory. Secondly, we note that Partisanship played a key role in determining the post-convention evaluations of both candidates. For Gore after the Republican convention, as awareness increased among Strong Republicans, the predicted change in feeling thermometer monotonically decreased. However, strong Democrats have a predicted higher evaluation over previous feeling thermometer evaluation that is monotonically increasing. Republican evaluations of Bush after the Democratic convention also exhibit the monotonic increase. However, strong Democratic partisans exhibit a slight non-monotonic evaluation over Bush, with those of a middle awareness ranking him higher. Therefore, the key determinant of the post-convention evaluation of the candidate not in convention is the partisanship of the respondent, with awareness levels causing a polarization effect.

\section{CONCLUSIONS}

In this paper, we have shown that there was greater partisan resistance to the message of Bush after the Republican 


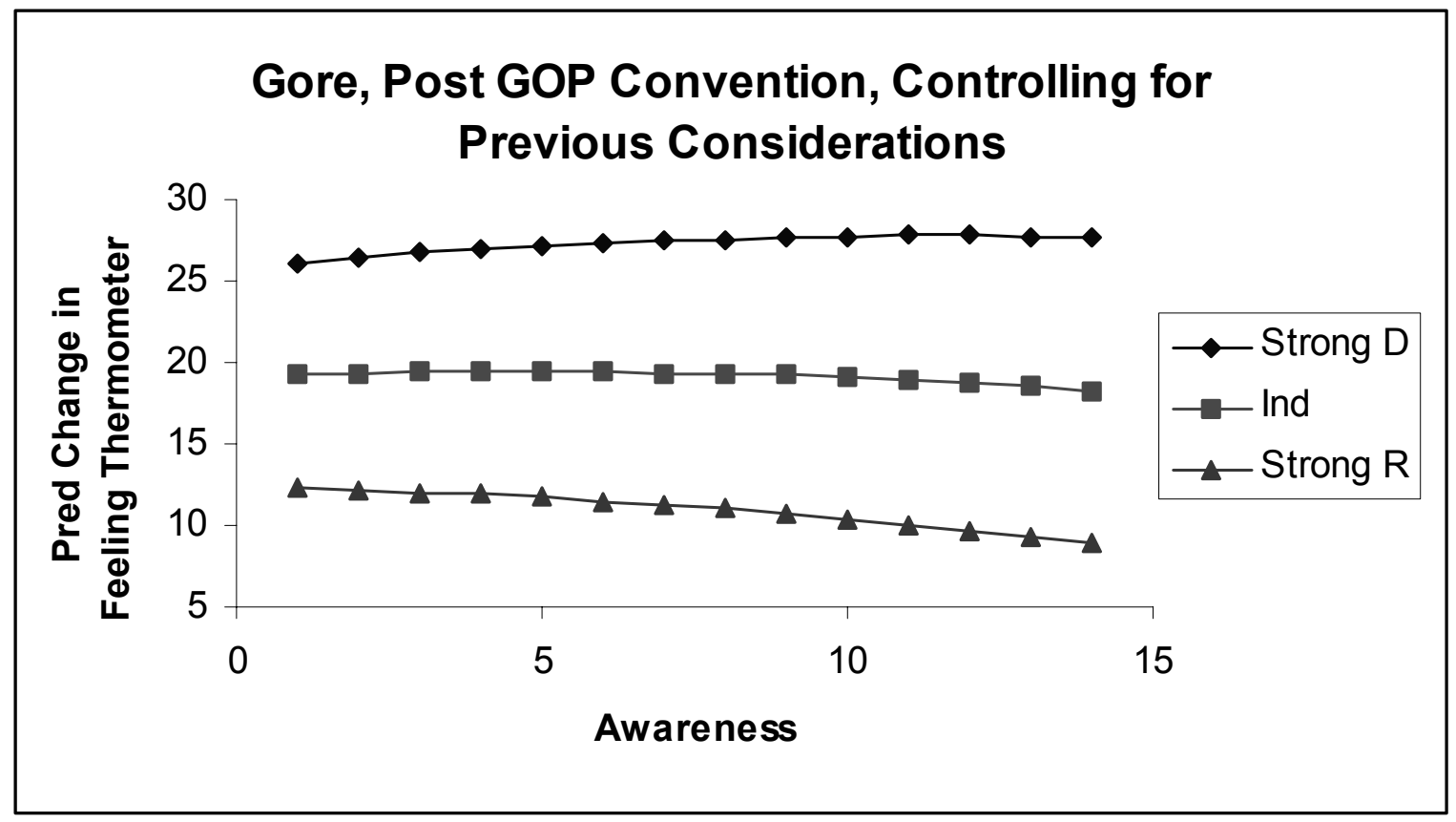

Graph 6. The predicted change in the Feeling Thermometer as a function of Awareness for Gore after the Republican Convention, controlling for previous considerations.

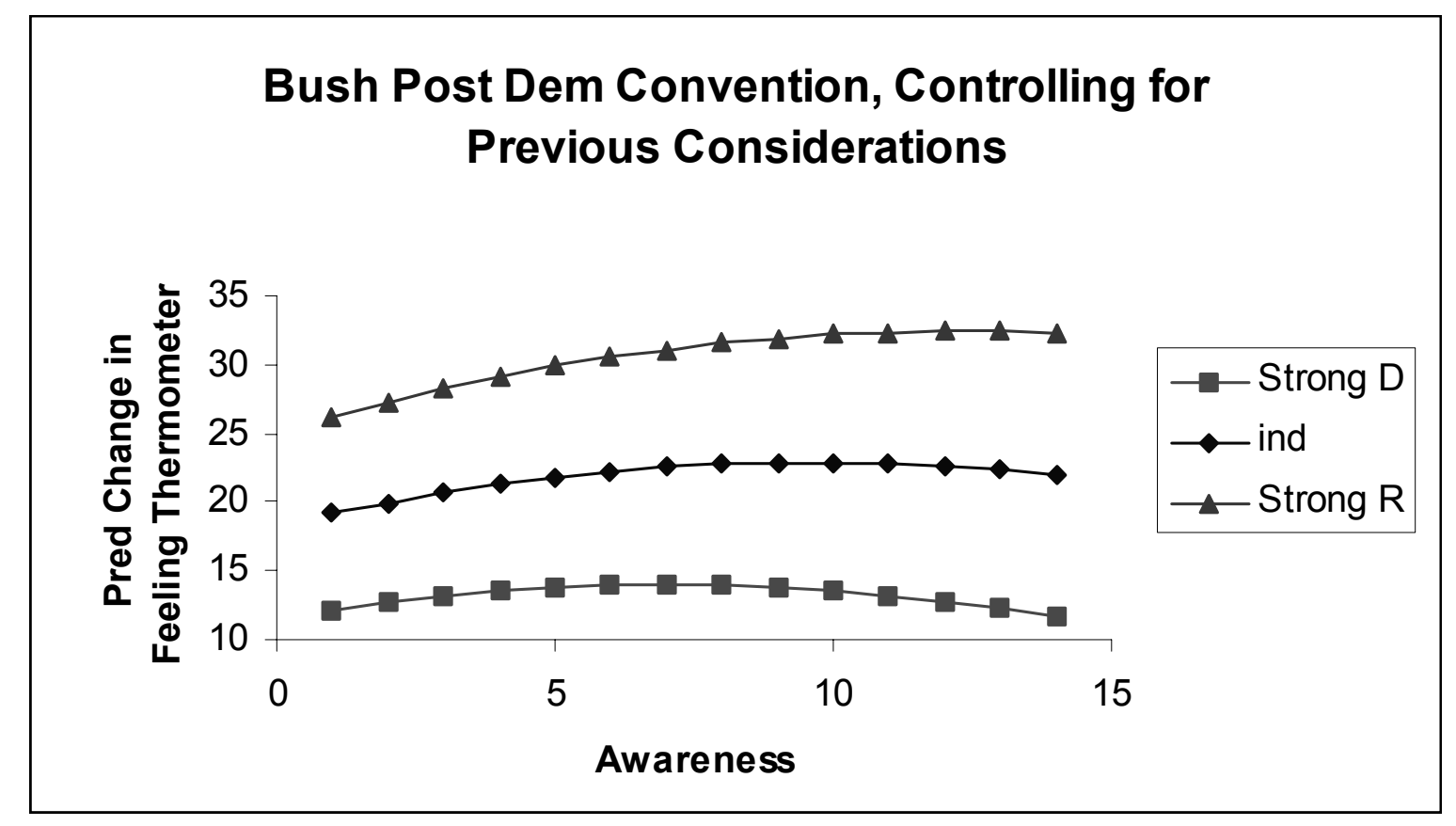

Graph 7. The predicted change in the Feeling Thermometer as a function of Awareness for Bush after the Democratic Convention, controlling for previous considerations.

convention and that awareness caused a greater non-monotonic "bend" in the predicted feeling thermometer for Gore, holding the previous feeling thermometer constant, after the Democratic convention. Further, Gore's message was better received than Bush's, with those with awareness levels from 5 to 14 having a 
higher predicted post-convention feeling thermometer. When a candidate is not in convention we see that the strong partisans are polarized, and that this partisanship plays the greatest role in determining how the predicted post-convention feeling thermometer appears in the simulation. What are the implications of these conclusions? First, from an historical perspective, we see that the aggregate level increase in support that Gore received after the Democratic convention is reflected in micro-level data from the nominating convention and that Gore's "bounce" after the Democratic convention was in fact stronger than the bounce that Bush received after the Republican convention. On a theoretical level we see that characteristics of respondents play a crucial role in the determination of post-convention evaluation. These characteristics interact to form the non-monotonic relationships seen in the analysis above. Therefore, those most likely to have a higher post-convention feeling thermometer ranking, holding previous feeling thermometer constant, are those with a mid-range of awareness, when analyzing evaluations for the candidate in convention. This offers empirical support for the application of the reception-acceptance model towards campaign conventions.

A primary concern has been the statistical imprecision of our model. However, as noted above, modern statistical theories show that the failure to reject a null hypothesis does not mean that an included variable is insignificant to the model: it is also important to situate the model in strong theoretical setting. Future research could offer varying constraints on equation 3 [1] that would limit the multi-collinearity in the model, eliminating some of the statistical imprecision.

The functional form in our analysis could also be critiqued. While we were able to capture the non-monotonic nature of opinion change over previous feeling thermometers, we were unable to bound the function, and therefore, there is the possibility that a predicted feeling thermometer might be out of range. Our model also suffers from simultaneous equation bias, with pre-convention feeling thermometer, itself a dependent variable, included in my model as an independent variable. Future versions of this paper will implement instrumental variable techniques to remove this bias. Further, our simplifying assumption of only one message during a convention should be revisited. It is possible that there are countervalent messages during a convention and that these could lead to a different functional form for estimation.

The interpretation of the data could be altered. Is the presidential nominating convention a prominent enough event that individuals will begin to keep an on-line tally of both candidates? If so, then the application of Zaller's functional form, and the interpretation after should be altered to create an on-line model. Future work could explore the possibility of employing an online model and the functional form that the on-line model's assumptions would imply [3].

\section{REFERENCES}

1. Grimmer, Justin, "Awareness, Partisanship and the Post-convention Bounce: A Memory-Based Model of Post-Convention Presidential Candidate Evaluations, Part 1-Introduction and Theoretical Analysis," Am. J. Undergrad. Res. 3(3), (2004), pp. 15-23.

2. Romer, Daniel, Kate Kenski, Paul Waldman, Christopher Adasiewicz and Kathleen Hall Jamieson. "Main Codebook" CD-ROM with Capturing Campaign Dynamics: The National Annenberg Election Study (Oxford University Press, New York, 2003), p. A5.

3. Zaller, John R. The Nature and Origins of Mass Opinion (Cambridge University Press, Cambridge, UK, 1992).

4. Grimmer, Justin. "An Empirical Investigation into the Effects of Education and Income on Voter Turnout," Working Paper, (Wabash College, Crawfordsville, Indiana, USA; 2003).

5. Merkel, Daniel, and Gary Langer. http://abcnews.go.com/images/pdf/826a 1AftertheConventions.pdf [First accessed on April 18, 2004]. 